\title{
Effect of Soil Contaminated by Diesel Oil on the Germination of Seeds and the Growth of Schinus terebinthifolius Raddi (Anacardiaceae) Seedlings
}

\author{
Cleusa Bona ${ }^{1 *}$, Igor Mendonça de Rezende ${ }^{2}$, Gedir de Oliveira Santos ${ }^{1}$ and Luiz Antônio de \\ Souza $^{3}$ \\ ${ }^{1}$ Departamento de Botânica; Universidade Federal do Paraná; C. P. 19031; 81531-990; Curitiba - PR - Brasil. \\ ${ }^{2}$ Universidade Federal do Paraná; Curitiba - PR - Brasil. ${ }^{3}$ Universidade estadual de Maringá; Maringá - PR - \\ Brasil
}

\begin{abstract}
The effect of soil polluted by diesel oil on the germination of seeds and the growth of Schinus terebinthifolius Raddi seedlings was analyzed at different times after contamination of the soil. The experiments were conducted under greenhouse conditions, with four treatments and five repetitions. The four treatments included: soil contaminated 30 (T30), 90 (T90) or 180 (T180) days before planting as well as a non-polluted soil (T0) (control). Soil saturated to $50 \%$ of its maximum retention capacity $(M R C)$ was contaminated with diesel oil at a rate of $92.4 \mathrm{~mL} \mathrm{per} \mathrm{kg}$. The germination rate and germination speed index (GSI) were significantly affected only in T30. The development of the plants was affected significantly in all the treatments, with reductions of biomass and eophyll area. It could be concluded that diesel oil significantly affected the germination, GSI and seedling growth of S. terebinthifolius, but the toxic effect decreased over the time.
\end{abstract}

Key words: Aroeira, biomass production, eophyll, residual contamination

\section{INTRODUCTION}

Diesel oil is a complex mixture of hydrocarbons such as low molecular weight alkanes and polycyclic aromatic hydrocarbons (PAHs) (Adam and Duncan, 1999). It also contains sulfur, nitrogen and oxygen in low concentrations as well as metals such as lead, nickel, sodium, calcium, copper and uranium (Posthuma, 1970). Diesel oil can cause chronic or acute effects in the plants. In addition to direct and indirect toxicity, the oil causes interference in the hydric relations of the plants. This interference, accompanied by the anaerobic and hydrophobic conditions, has been found to be the most important effect of diesel oil contaminated soil on seed germination and plant growth (Racine, 1994).

It is known that the hydrocarbons, in particular the polycyclic aromatic hydrocarbons (PAHs), are toxic to the plants, but little research has been done on plant responses to the stress caused by the aromatic hydrocarbons. Alkio et al. (2005) observed several effects of phenanthrene, PAH, in Arabidopsis, including reduction in the growth of the stem and the root, deformed trichomes, reduced radicular hairs, degradation of the

*Author for correspondence: cleusabona@ufpr.br 
chlorophyll, delayed blooming and the appearance of white dots that developed into necrotic lesions. At the cellular level, plants showed signs of oxidative stress, including the production of hydrogen peroxide $\left(\mathrm{H}_{2} \mathrm{O}_{2}\right)$ and cellular death.

Many authors have reported a lower rate of germination in soil contaminated by petroleum or its derivatives (Amakiri and Onofeghara, 1984; Adam and Duncan, 1999, 2002; Vavrek and Campbell, 2002; Méndez-Natera et al., 2004; Achuba, 2006; Smith et al., 2006, Sharifi et al., 2007; Korade and Fulekar, 2009; Ogbo, 2009). According to Baker (1970) and Adam and Duncan (2002), petroleum hydrocarbons may form a film on the seed, preventing the entry of oxygen and water. Achuba (2006) reported that toxic hydrocarbon molecules could inhibit the activities of amylase and starch phosphorylase and thereby affecting the assimilation of starch. Henner et al. (1999) reported that petroleum hydrocarbons consisting of small molecules and those that are water soluble are more phytotoxic for the germination. However, there have been reports describing the species whose germination was not affected by the presence of oil in the ground (Adam and Duncan, 2002; Merkl et al., 2004; Gogosz et al., 2010).

The symptoms caused by the contamination with oil are countless and are generally not specific. The same substance can induce different effects in different species, and conversely, the same symptoms can arise from exposure to different substances (Baker, 1970). The most common and important symptoms observed in the plants contaminated with oil and its byproducts include the erosion of the epicuticular wax (Baker, 1970), degradation of chlorophyll (Baker, 1970; Malallah et al., 1996 and 1998), alterations in the stomatal mechanism (Baker, 1970), reduction in photosynthesis and respiration (Baker, 1970), increase in the production of stress-related phytohormones (Larcher, 2000), accumulation of toxic substances or their byproducts in vegetal tissue (Baker, 1970), decrease in size and less production of biomass (Proffitt et al., 1995; Green et al., 1996; Kuhn et al., 1998; Brandt et al., 2006; Daniel-Kalio and Pepple, 2006; Adenipekun et al., 2008).

In some cases after an oil spill, an increase in the production of biomass and in the growth and development of some species can be observed. This likely occurs for three reasons: i) the oil may kill some organisms present in the soil, increasing the organic matter available; ii) some compounds that regulate the plant growth could be present in the oil; and iii) nitrogen fixation may increase with the presence of oil in the soil (Baker, 1971). At present, there are several methods aimed at minimizing the negative effects of soil contamination. Phytoremediation uses plants and their associated microorganisms to restore or recover the degraded areas. Recent studies have shown that an increase in the degradation of oil hydrocarbons occurs in the soils inhabited by the plants (Muratova et al., 2003). One of the first steps in the selection of the plants for phytoremediation is the identification of species able to grow and develop in oil-contaminated soil, followed by an evaluation of the species' role in the degradation of oil hydrocarbons and their byproducts (Merkl et al., 2004).

S. terebinthifolius is native to Brazil and exotic in several countries in Europe, Central America and the southern United States, where it has become invasive (Carvalho, 2003). It is a melliferous pioneer species frequently visited by the birds and is important in the recovery of degraded areas (Lorenzi, 1992). As such, it is an important species to test for resistance to the soil contaminated with petroleum derivatives.

The objective of this study was to investigate the effect of soil contaminated with diesel oil, after different length periods of contamination, on the germination and development of $S$. terebinthifolius seedlings. Two hypotheses were tested: i) the presence of diesel fuel in the soil alter germination and seedling growth, and ii) if the first hypothesis was confirmed, the toxic effects decreased over the time?

\section{MATERIALS AND METHODS}

Mature fruits of Schinus terebinthifolius Raddi were collected in Tunas-PR, Brazil, and packed in hermetically sealed plastic bags at $6.7 \%$ humidity. Before planting, the diaspores were rehydrated and peeled, isolating the seeds. These were then tested for viability, with $60 \%$ germination. The soil was collected in Araucária-PR, where $S$. terebinthifolius occurred naturally, and was classified as melanic gley soil with a superficial accumulation of organic matter and a clay-like texture (Fasolo et al., 2002). The soil was then 
dried, sifted, homogenized and placed in the trays, with approximately $3 \mathrm{~kg}$ of dry soil per tray. The soil was saturated to $50 \%$ of its maximum retention capacity (MRC), based on the studies by Muratova et al. (2003) and Li et al. (1997), which used 40 and $70 \%$ MRC, respectively. The quantity of diesel oil per $\mathrm{kg}$ of soil was defined by the maximum quantity retained in the soil previously hydrated with $50 \%$ of its MRC; the value obtained was $92.4 \mathrm{~mL}$ of diesel oil per $\mathrm{kg}$ of soil.
After the contamination of the soil, the trays were kept in a greenhouse exposed to an internal nebulization of 15 seconds every $3 \mathrm{~h}$ until planting. Before planting, the soil was characterized chemically and physically (Table 1). After planting, the nebulization was altered to 5 seconds every 20 minutes, and the temperature ranged from $8.7^{\circ} \mathrm{C}$ (at night) to $37.8^{\circ} \mathrm{C}$ (during the day). The experiment consisted of five repetitions (trays) with three treatments and 1 control.

Table 1 - Chemical and physical analyses of contaminated and uncontaminated (control) soil by diesel oil.

\begin{tabular}{|c|c|c|c|c|c|c|c|c|c|}
\hline \multirow{2}{*}{ Sample } & pH & $\mathrm{Al}^{+3}$ & $\mathbf{C a}^{+2}$ & $\mathrm{Mg}^{+2}$ & $\mathbf{K}^{+}$ & $\mathbf{P}$ & $\mathrm{C}$ & $\mathrm{Ca} / \mathrm{Mg}$ & clay \\
\hline & $\mathrm{CaCl}_{2}$ & \multicolumn{4}{|c|}{$\mathbf{c m o l}_{\mathbf{c}} / \mathbf{d m}^{3}$} & $\mathrm{Mg} / \mathrm{dm}^{3}$ & $g / d^{3}$ & $\%$ & g/kg \\
\hline Contaminated Soil & 5.60 & 0.00 & 12.80 & 7.00 & 0.43 & 7.00 & 38.9 & 1.8 & 400.0 \\
\hline Control Soil & 6.10 & 0.00 & 12.20 & 7.40 & 0.71 & 8.80 & 30.5 & 1.6 & 400.0 \\
\hline
\end{tabular}

The treatments differed in the number of days after soil contamination with diesel oil before planting seeds: 180 (T180), 90 (T90) and 30 (T30) days. The control treatment (T0) consisted of uncontaminated wet soil saturated to $50 \%$ of its MRC. Planting for all the treatments took place at the same time in January 2005. In each repetition (tray), 50 seeds were used, totaling $\mathrm{n}=250$ seeds per treatment. The experiment was analyzed according to a completely randomized design (CRD).

The germination evaluation was conducted daily for 20 days. A morphological criterion was adopted to evaluate the experiment, with the seed considered to be germinated when the primary root appeared. Germinated seeds were counted, and the percentage of germination $(\% \mathrm{G})$ and germination speed index (GSI) were calculated according to Maguire's (1962) formula. Thirty days after the germination, 25 individuals from each treatment were collected to measure their fresh biomass (FB) and total height (principal root to the top of the stem) $(\mathrm{H})$ of the seedling. These were pressed in the paper and dehydrated at $70^{\circ} \mathrm{C}$ for approximately $24 \mathrm{~h}$. After dehydration, the total dry biomass (DB) was measured, and eophylls were separated to weigh and measure their foliar area (FA). Foliar area was calculated using SigmaProß Version 2.1 with scanned images of the leaves. The nomenclature of the seedlings was defined according to Souza (2003).

All the variables were analyzed statistically using variance analyses (ANOVA), with the DMS determined by the Tukey test, at a level of significance of $5 \%$. The statistical program used was JUMP 5.0.1.

\section{RESULTS}

Diesel oil caused a significant reduction in the germination of the seeds only in the treatment T30. The number of germinated seeds was significantly lower in the treatment T30 compared to all the treatments (Fig. 1). In T0, T90, T180 and T30 $53.6,53.2,50.0$ and $29.6 \%$ of the seeds germinated, respectively. The germination speed index was similar in the treatments T0 (12.48), T90 (12.77) and T180 (12.18) but was significantly lowest in the treatment T30 (6.82). The appearance of the primary root occurred on about the $6^{\text {th }}$ day, presenting white coloring in the apex and brown coloring in the region of the radicular hairs. The seedlings were phanerocotylar and epigeous. After the first week, the cotyledons were freed from the tegument. The expansion of cotyledons was slower in the contaminated soil. Expansion occurred between the $9^{\text {th }}$ and $13^{\text {th }}$ days in uncontaminated soil (T0), between the $11^{\text {th }}$ and $15^{\text {th }}$ days in the treatments $\mathrm{T} 180$ and $\mathrm{T} 90$, and between the $13^{\text {th }}$ and $20^{\text {th }}$ days in the treatment T30. Starting from day 30, most of the seedlings in the uncontaminated soil had expanded eophylls. In the treatments T180 and T90, the eophylls expanded beginning on the $29^{\text {th }}$ day, and in the treatment T30, they expanded on the $30^{\text {th }}$ day (Fig. 
2A). The first before planting) and T0 (uncontaminated soil). Each column represented the mean of the five replications; bars indicated the standard deviation. The means for each treatment followed by different letters were significantly different at $\mathrm{p}<0.05$. The pair of eophylls was simple and opposite (Fig. 2B). In general, the eophylls of seedlings grown in the soil contaminated with the diesel oil presented red coloring in contrast with the seedlings grown in uncontaminated soil. Thirty days after the planting, individuals from the treatments T30, T90 and T180 displayed expanded cotyledons and eophylls that were beginning development. In contrast, most seedlings from the uncontaminated control (T0) had completely developed eophylls, and their first real leaves (nomophyll) had expanded (Fig. 2A) by 30 days after the planting.

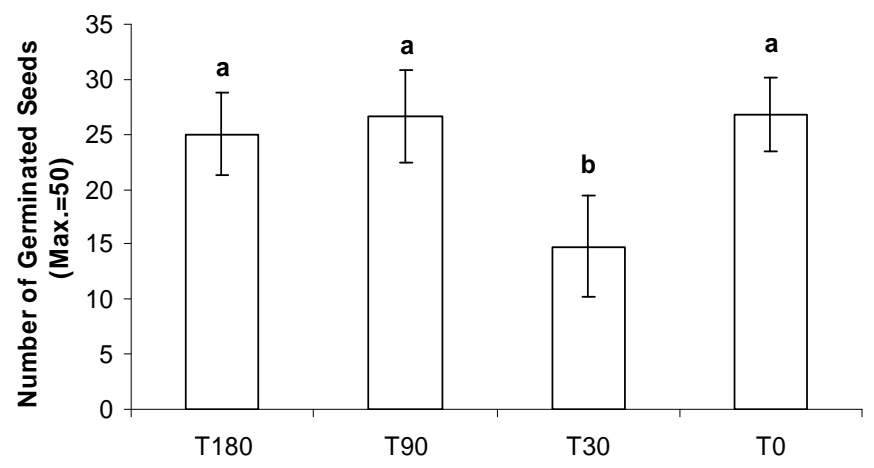

Figure 1 - Number of Schinus terebinthifolius Raddi seeds germinated up to 20 days after planting in treatments T180 (soil contaminated 180 days before planting), T90 (soil contaminated 90 days before planting), T30 (soil contaminated 30 days.
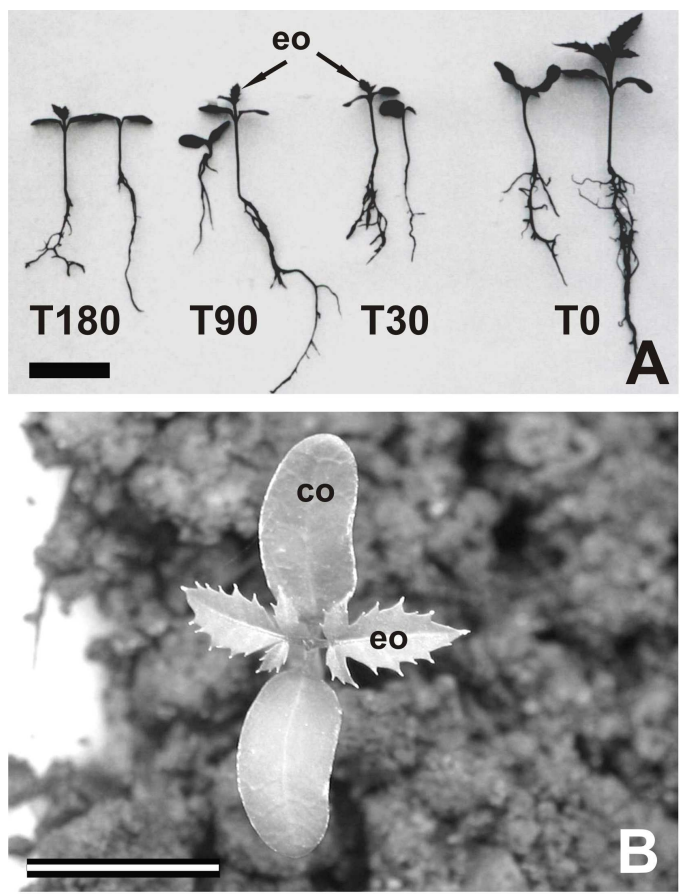

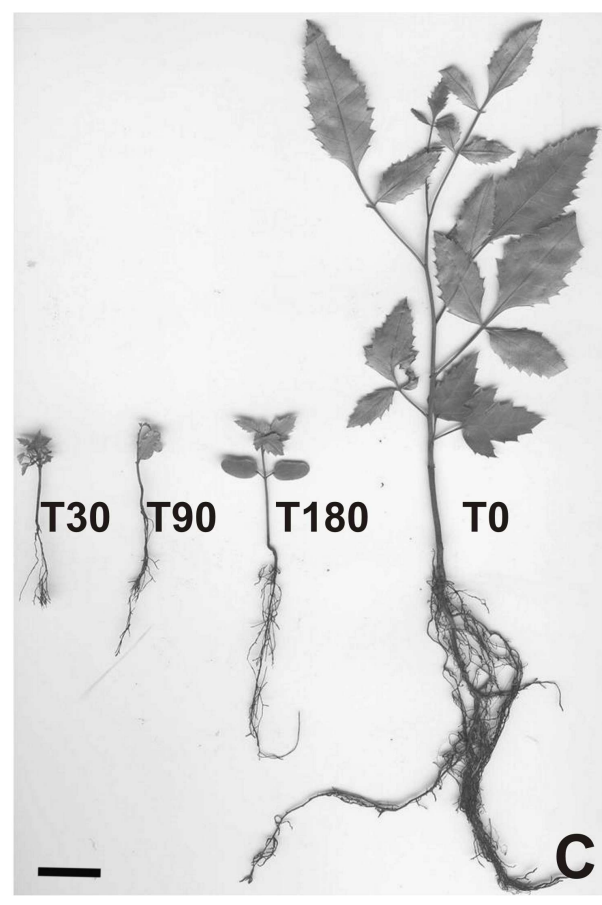

Figure 2 - Schinus terebinthifolius seedlings growing in soil contaminated by diesel oil: treatments T180 (soil contaminated 180 days before planting), T90 (soil contaminated 90 days before planting), T30 (soil contaminated 30 days before planting) and T0 (uncontaminated soil). A: 30-day-old seedlings; B: 45- day-old seedlings in T30 contaminated soil; $\mathrm{C}$ : 90-day-old seedlings. $(\mathrm{co})=$ cotyledon, $(\mathrm{eo})=$ eophyll. $\mathrm{Bar}=2$ $\mathrm{cm}(\mathrm{A}$ and $\mathrm{C}), \mathrm{Bar}=1 \mathrm{~cm}(\mathrm{~B})$. 
The number of days after the contamination of the soil only affected the height of the seedlings in the treatment T30, while the seedling heights in the treatments T90 and T180 were similar to those in the control group (Fig. 2A and 3). The difference in the growth between the control seedlings and the rest of the treatments was most evident 90 days after the planting, when the control seedlings were nearly three times as tall as those in the rest of the treatments (Fig. 2C).
The presence of diesel oil in the soil negatively affected the fresh and dry biomass of the seedlings in all of the treatments. The results for the dry biomass of seedlings were similar to those for fresh biomass (Fig. 4A and B). Diesel oil caused a major reduction in dry biomass and eophyll foliar area in all the treatments with contaminated soil, and this was most pronounced in the treatment T30 (Fig. 4C and D).

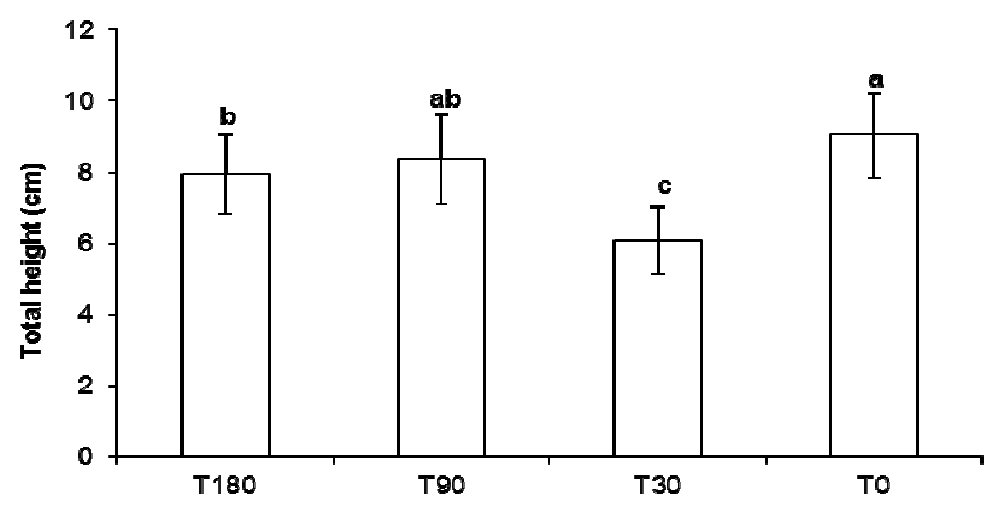

Figure 3 - Total height of seedlings of Schinus terebinthifolius Raddi (30 days after planting) in treatments T180 (soil contaminated 180 days before planting), T90 (soil contaminated 90 days before planting), T30 (soil contaminated 30 days before planting) and T0 (uncontaminated soil). Each column represents the mean of the five replications; bars indicate standard deviation. Means for each treatment followed by different letters are significantly different at $\mathrm{p}<0.05$.
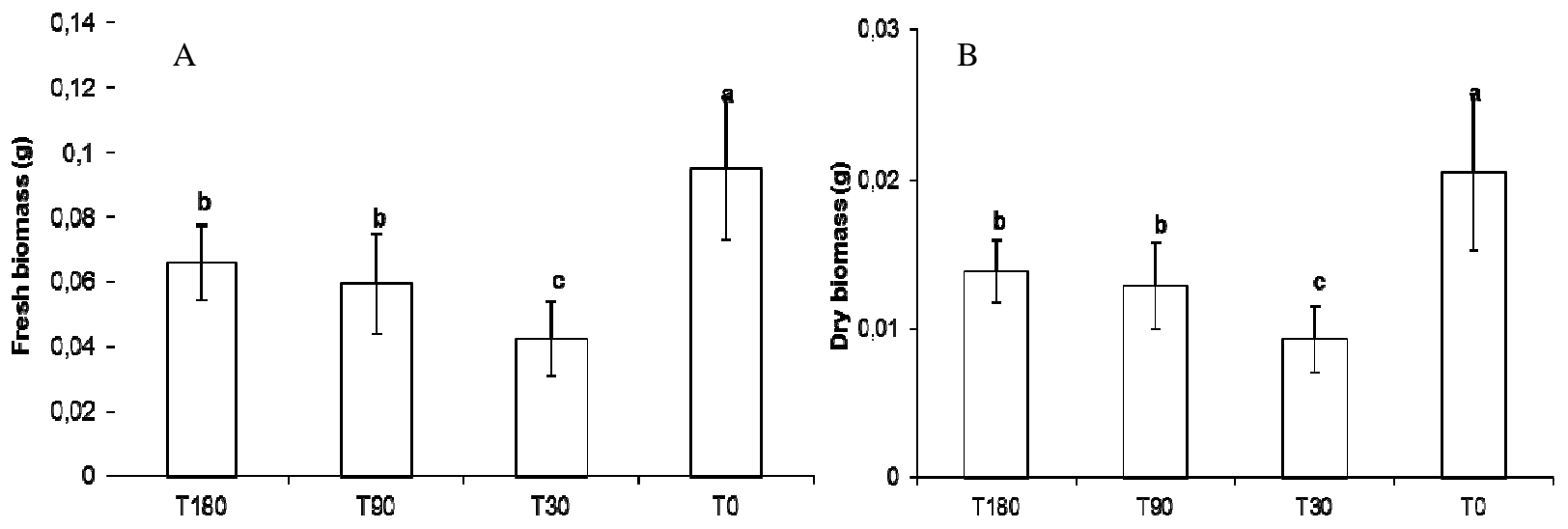

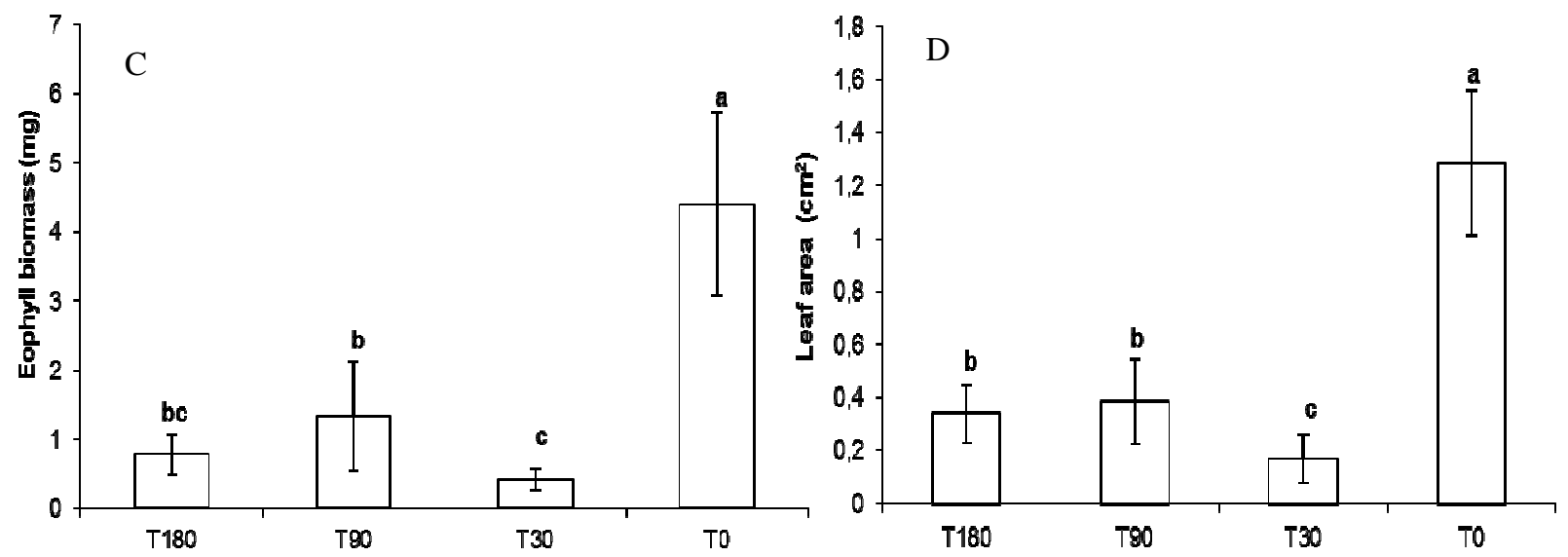

Figure 4 - (A) Fresh Biomass, (B) Dry Biomass (C), Eophyll foliar Biomass (D) and Eophyll foliar area of Schinus terebinthifolius Raddi seedlings 30 days after planting. T180 (soil contaminated 180 days before planting), T90 (soil contaminated 90 days before planting), T30 (soil contaminated 30 days before planting) and T0 (uncontaminated soil). Each column represents the mean of the five replications; bars indicate standard deviation. Means for each treatment followed by different letters are significantly different at $p<0.05$.

\section{DISCUSSION}

The treatment with the most strongly affected germinability was $\mathrm{T} 30$, in which contamination was most recent prior to the planting. The lowest germination speed index (GSI), approximately $50 \%$ lower than the rest of the treatments, was also recorded for the treatment T30. These results clearly indicated that the longer the time between the contamination and planting, the more efficient was the germination of $S$. terebinthifolius seeds. Similar results were found by Bossert and Bartha (1985), who registered low germinability of corn seeds in the soil contaminated by the crude oil, and by Gallegos-Martínez et al. (2000), who found a reduction in the germination between 30 and $90 \%$ in the tropical native Mexican species subjected to soil contaminated with crude oil. Adam and Duncan (2002) also observed that the degree of alteration in germination of the seeds in gramineous, herbaceous and leguminous plants was affected by the amount of time that passed after the contamination. These authors recorded higher germination of the seeds in the soil contaminated three weeks before the planting than in the soil contaminated on the day of the planting. According to Adam and Duncan (2002), diesel oil has a volatile component that contains light hydrocarbons capable of entering easily through the plant cell walls. These small hydrocarbon molecules that penetrate the plants can be phytotoxic, explaining the delay in the germination and decrease in seed germination(Adam and Duncan, 2002; Ogbo, 2009). In the present study, the higher rates of germination in the treatments T90 and T180 were probably due to the reduction of volatile hydrocarbons.

Another explanation for the germination delay, lower germination rate and lower GSI observed in the treatment T30 could be the physical barrier caused by the diesel oil enveloping the seed (Baker, 1970). The shorter period of time between the contamination and planting in this treatment could have allowed diesel oil, which was hydrophobic, to cover the seeds, producing a barrier to the passage of water and possibly gases to the interior of the seed. According to Henner et al. (1999), the more recent the contamination, the higher were the concentration of volatile compounds and water-soluble compounds, which were most detrimental to germination. In addition, saturation of the seed and gas exchange are the initial stages in the germination process (Labouriau, 1983). Any interference during these stages can affect the germination, explaining the low germinability and the delay in the GSI found in treatment T30. Merkl et al. (2004), studying the germination of two gramineous and six tropical leguminous plants from Venezuela in the soil contaminated with crude oil, did not observe alteration in the germination, except in Desmodium glabrum (Mill.) DC. However, Leck 
and Simpson (1992), examining the appearance of the seedlings in a seed bank after the application of oil, registered a $30 \%$ reduction in the germination. $S$. terebinthifolius seeds experienced a reduction in the germination of almost $50 \%$, showing that the effect of oil on the germination varied according to the species.

Reduced growth of the seedlings in the contaminated soil has also been recorded for other species. Kuhn et al. (1998) reported a decrease in the size of Lycopersicon esculentum Mill. (Solanaceae) seedlings grown in oil-contaminated soil. The same phenomenon was reported by Proffitt et al. (1995) in Rhizophora mangle L. (Rhizophoraceae) seedlings growing in the soil contaminated by oil, with a $50 \%$ reduction in the growth. In both the experiments, the contaminant was added directly to the soil, with no time interval between the contamination and planting. Adenipekun et al. (2008) concluded that the shorter length of seedlings of Corchorus olitorius L. (Tilicaceae) in the soil contaminated with oil was caused by the reduced water availability in the soil. According to Hester and Mendelssohn (2000), the growth of the plants could be hindered by the physical and chemical alterations in the soil caused by oil. The presence of hydrocarbons can change the fertility of the soil (Wyszkowska et al., 2001, 2002). Therefore, a nutritional imbalance may have occurred in the seedlings in the contaminated soils, resulting in lower growth and biomass production.

The biomass reduction of the seedlings grown in the contaminated soil was also observed for other species by Merkl et al. (2004) and Chaîneau et al. (1997), who found the individuals grown in the soil contaminated by the crude oil. The authors recorded a reduction of 85 and $99 \%$ in the biomass of Brachiaria brizantha (Hochst. ex A. Rich.) Stapf (Poaceae) and Panicum maximum Jacq. (Poaceae), respectively. Brandt et al. (2006) found evidence that the reduced growth and biomass found in Vetiveria zizanioides (L.) Nash (Poaceae) in the contaminated soil was related to the nutrients content. Daniel-Kalio and Pepple (2006) found that the time interval between the contamination and the establishment of seedlings affected the biomass of Commelina benghalensis L. (Commelinaceae). The same authors concluded that the time interval influenced the degradation of hydrocarbons and the availability of nutrients.

The development of eophylls was affected by the oil, producing lower biomass and foliar area.
Chupakhina and Maslennikov (2004) reported the late development of eophylls in the seedlings of Vicia sativa L. (Fabaceae), Panicum miliaceum L. (Poaceae) and Hordeum vulgare L. (Poaceae). Proffitt et al. (1995), studying Rhizophora mangle L. (Rhizophoraceae) seedlings, observed a decrease in dry biomass and foliar area in the individuals grown in oil-contaminated soil. However, Mayer et al. (2005) did not observe a significant difference between the dry biomass, foliar area and leaf-specific foliar area of Campomanesia xanthocarpa O. Berg (Myrtaceae) seedlings in oil-contaminated soil and control seedlings. Adenipekun et al. $(2008,2009)$ reported that Corchorus olitorius seedlings in oilcontaminated soil had a lower number of the leaves and reduced leaf area compared to those in uncontaminated soil. It is clear that the plants react in different ways to contaminants and that the seedlings are more susceptible to the contamination. The decrease in the size of leaves is likely a result of reduced absorption of the nutrients and water, affecting the development of the aboveground system because such absorption is essential for the growth of the plant (Proffitt et al., 1995; Adenipekun et al., 2009). However, Alkio et al. (2005) reported that the decrease in size and number of leaves of Arabidopsis thaliana (L.) Heynh. (Brassicaceae) in the soil contaminated with phenanthrene was caused by the toxic effect of contaminant uptake by the plants. Agbogidi et al. (2006) suggested that the reduced number of leaves and leaf area reported for Dennettia tripetala Baker f. (Annonaceae) growing in the contaminated soil was caused by the water stress resulting from the immobilization of the nutrients and by the changes in the activity of some metabolites within the plant.

\section{CONCLUSION}

Diesel oil affected the germination of $S$. terebinthifolius only in the treatment in which planting occurred 30 days after soil contamination. Diesel oil significantly affected the seedling growth of S. terebinthifolius, but the toxic effect decreased over the time. Because of the ability of $S$. terebinthifolius seedlings to grow and develop in oil-contaminated soil, this native species should be evaluated as a candidate for phytoremediation in the soils with hydrocarbons from oil. 


\section{ACKNOWLEDGEMENTS}

The authors thank the Embrapa Florestas Researcher, Antônio Carlos Medeiros, for providing the diaspores of $S$. terebinthifolius and to CAPES for the Masters scholarship.

\section{REFERENCES}

Achuba, F. I. (2006), The effect of sublethal concentrations of crude oil on the growth and metabolism of Cowpea (Vigna unguiculata) seedlings. Environmentalist, 26, 17-20.

Adam, G. and Duncan, H. J. (1999), Effect of diesel fuel on growth of selected plant species. Environ. Geochem.Hlth., 21, 353-357.

Adam, G. and Duncan, H. J. (2002), Influence of Diesel Fuel on Seed Germination. Environ.Pollut., 120, 363 370.

Adenipekun, C. O., Oyetunji, O. J. and Kassim, L. Q. (2009), Screening of Abelmoschus esculentus L. moench for tolerance to spent engine oil. J. Appl.Biosci., 20, 1131 - 1137.

Adenipekun, C. O., Oyetunji, O. J. and Kassim, L. S. (2008), Effect of spent engine oil on the growth parameters and chlorophyll content of Corchorus olitorius Linn. Environmentalist, 28, 446-450.

Agbogidi, O. M., Onosode, A. T. and Okonta, B. C. (2006), Susceptibility of Dennettia tripetala (Bak.) f. seeds to crude oil. J. Food Agr. Environ., 2, 350-352.

Alkio, M., Tabuchi, T. M., Wang, X. and Colón-Carmona, A. (2005), Stress responses to polycyclic aromatic hydrocarbons in Arabidopsis include growth inhibition and hypersensitive response-like symptoms. J. Exp. Bot., 56, 2983-2994.

Amakiri, J. O. and Onofeghara, F. A. (1984), Effects of crude oil on the germination of Zea mays and Capsicum frutescens. Environ. Pollut., 35, 159-167.

Baker, J.M. (1970), The effects of oils on plants. Environ. Pollut., 1, 27-44.

Baker, J.M. (1971) Growth stimulation following oil pollution. In: Cowell EB (ed) The ecological effects of oil on pollution and littoral communities. London Inst. of Petroleum, 72-77.

Bossert, I. and Bartha, R. (1985), Plant growth on soil with a history of oil sludge disposal. Soil Science, 140, 75-77.

Brandt, R., Merkl, N., Schultze-Kraft, R., Infante, C. and Broll, G. (2006), Potential of vetiver (Vetiveria zizanioides (L.) Nash) for phytoremediation of petroleum hydrocarbon-contaminated soils in Venezuela. Int. J. Phytoremed., 8, 273-284.

Carvalho, P. E. R. (2003), Espécies arbóreas Brasileiras. Editora Embrapa Informação Tecnológica, Brasília, 161168.

Chaîneau, C. H., Morel, J. L. and Oudot, J. (1997), Phytotoxicity and plant uptake of fuel oil hydrocarbons. J. Environ. Qual., 26, 1478-1483.

Chupakhina, G. N., Maslennikov, P. V. (2004), Plant adaptation to oil stress. Russ. J. Ecol., 35, 290-295.

Daniel-Kalio, L. A. and Pepple, S. F. (2006), Effect of bonny light crude oil pollution of soil on the growth of dayflower (Commelina benghalensis L.) in the Niger Delta, Nigeria. J. Appl. Sci. Environ. Mgt., 10, 111-114.

Fasolo, P. J., Bognola, I. A., Carvalho, A. P., Pooter, R. O. E. and Bhering, S. B. (2002), Levantamento de Reconhecimento dos Solos da Região Sudeste do Estado do Paraná (área 4, 5 e 6). Boletim de Pesquisa e Desenvolvimento - EMBRAPA.

Gallegos-Martínez, M., Gómez Santos, A., González Cruz, L., Montes de Oca García, M. A., Yañez Trujillo, L., Zermeño Eguia Liz, A. and Gutiérrez-Rojas, M. (2000), Diagnostic and resulting approaches to restore petroleum contaminated soil in a Mexican tropical swamp. Water. Sci. Tech., 42, 377-384.

Gogosz, A.M., Bona, C.B., Santos, G.O. and Botosso, P.C. (2010), Germination and initial growth of Campomanesia xanthocarpa O. Berg. (Myrtaceae), in petroleum-contaminated soil and bioremediated soil. Braz. J. Biol., 70, (in press).

Green, B. T., Wiberg, C. T., Woodruff, J. L.; Miller, E. W., Poage, V. L., Childress, D. M., Feulner, J. A., Froshc, S. A., Runkel, J. A., Wanderscheid, D. M., Wierma, M. D., Yang, X., Choe, H. T. and Mercurio, S. D. (1996), Phytotoxicity observed in Tradescantia correlates with diesel fuel contamination in soil. Environ. Exper. Bot., 6, 313-321.

Henner, P., Schiavon, M., Druelle, V. and Lichtfouse, E. (1999), Phytotoxicity of ancient gaswork soils. Effect of polycyclic aromatic hydrocarbons (PAHs) on plant germination. Organic Geochemistry, 30, 963-969.

Hester, M. W. and Mendelssohn, I. A. (2000), Long-term recovery of a Louisiana brackish marsh plant community form oil-spill impact: vegetation response and mitigation effects of marsh surface elevation. Mar. Environ. Res., 49, 339-347.

Korade, D.L. and Fulekar, M. H. (2009), Effect of organic contaminants on seed germination of Lolium multiflorum in soil. Biology and Medicine (Bio. Med.), 1, 28-34.

Kuhn, W., Gambino, R., Al-Awadhi, N., Balba, M. T. and Dragun, J. (1998), Growth of tomato plants in soil contaminated with Kuwait crude oil. J. Soil Contam., 7, 801-806.

Labouriau, L. G. (1983), A germinação de Sementes. Washington, D.C.: OEA, $240 \mathrm{pp}$.

Larcher, W. (2000), Ecofisiologia Vegetal. RiMa, São Carlos, 365 pp.

Leck, M. A. and Simpson, R. L. (1992), Effect of oil on recruitment from the seed bank of two tidal freshwater. Wetl. Ecol. Manag, 4, 223-231.

Li, X., Feng, Y. and Sawatsky, N. (1997), Importance of soil-water reltions in assessing the endpoint of bioremediated soils. Plant and Soil, 192, 219-226.

Lorenzi, H. (1992), Árvores Brasileiras; Manual de Identificação e Cultivo de Plantas Arbóreas Nativas do Brasil, 1 ed. Instituto Plantarum.

Maguire, J. D. (1962), Speed of germination-aid in selection and evaluation for seedling emergence and vigor. Crop Sci., 2, 176-177.

Malallah, G., Afzal, M., Gulshan, S., Kurian, M. and Dhami, M. S. I. (1996), Vicia faba as a bioindicator of oil pollution. Environ. Pollut., 92, 213-217. 
Malallah, G., Afzal, M., Kurian, M., Gulshan, S. and Dhami, M.S.I. (1998), Impact of oil pollution on some desert plants. Environ. Int., 24, 919-924.

Mayer, J. L. S., Bona, C., Santos, G. de O. and Koehler, H. S. (2005), Efeito do solo contaminado com petróleo no crescimento e desenvolvimento de Campomanesia xanthocarpa O. Berg. (Myrtaceae). IV Simpósio Nacional e Congresso Latino-americano de Recuperação de Áreas Degradadas, Curitiba, Paraná, Brasil. Anais, p.299-306.

Méndez-Natera, J. R., Roque, C., Zapata, K. and OtaholaGómez, V. (2004), Efecto de la concentración y tiempo de contaminación de un suelo por petróleo en la germinación de semillas de maíz (Zea mays L.) cv. Himeca 95. Revista UDO Agrícola, 4, 66-71.

Merkl, N., Schultze-Kraft, R. and Infante, C. (2004), Phytoremediantion in the tropics - The effect of oil on the growth of tropical plants. Biorem. J., 8, 177-184.

Muratova, A. Y., Turkovskaya, O. V., Hübner, T. E. and Kuschk, P. (2003), Studies of the Efficacy of Alfalfa and Reed in the Phytoremediation of Hydrocarbon-Polluted Soil. Appl. Biochem. Microbiol., 39, 681-688.

Ogbo, E. M. (2009), Effects of diesel fuel contamination on seed germination of four crop plants - Arachis hypogaea,Vigna unguiculata, Sorghum bicolor and Zea mays. African J. Biotechn., 8, 250-253.

Posthuma, J. (1970), The composition of petroleum. Rapp. P. v. reun. Cons. perm. int. Explor. Mer., 171, 7-16.

Proffitt, C. E., Devlin, D. J. and Lindsey, M. (1995), Effects of oil on mangrove seedlings grow under different environmental conditions. Mar. Pollut. Bull., 30, 788-793.
Racine, C.H. (1994), Long-term recovery of vegetation on two experimental crude oil spills in interior Alaska black spruce taiga. Can. J. Bot., 72, 1171-1177.

Sharifi, M., Sadeghi, Y. and Akbarpour, M. (2007), Germination and growth of six plant species on contaminated soil with spent oil. Int. J. Environ. Sci. Tech., 4, 463-470.

Smith, M. J., Flowers, T. H., Duncan, H. J. and Alder, J. (2006), Effects of polycyclic aromatic hydrocarbons on germination and subsequent growth of grasses and legumes in freshly contaminated soil and soil with aged PAHs residues. Environ. Pollut., 141, 519-525.

Souza, L. A. (2003), Morfologia e Anatomia Vegetal, UEPG, Ponta Grossa.

Udo, E. J. and Fayemi, A. A. (1975), The effects of oil pollution of soil on germination, growth and nutrient uptake of corn. J. Environ. Qual., 4, 537-540.

Vavrek, M. C. and Campbell, W. J. (2002), Contribution of seed banks to freshwater wetland vegetation recovery. Louisiana Applied and Educational Oil Spill Research and Development Program, OSRADP. Technical Report Series, 0-12.

Wyszkowska, J., Kucharski, J., Jastrzçbska, E. and Hlasko, A. (2001), The biological properties of the soil as influenced by chromium contamination. Polish $J$. Environ. Stud., 10, 37-42.

Wyszkowska, J., KUCHARSKI, J. and Waldowska, E. (2002), The influence of diesel oil contamination on soil microorganisms and oat growth. Rostlinná Výroba, 48, 51-57. 
